\title{
Impaired blood pressure response to exercise in patients with coronary artery disease: possible contribution of attenuated reflex vasoconstriction in non-exercising muscles
}

\author{
SHUICHI OKAMATSU, AKIRA TAKESHITA, MOTOOMI NAKAMURA \\ From the Research Institute of Angiocardiology and Cardiovascular Clinic, Faculty of Medicine, Kyushu \\ University, Fukuoka, Japan
}

SUMMARY Eighteen patients with coronary artery disease were divided into two groups according to whether their blood pressure decreased (eight, group 1) or increased (10, group 2) in response to treadmill exercise testing. Age and the extent and distribution of coronary artery disease were similar in the two groups. At rest, blood pressure, pulmonary artery wedge pressure, cardiac index, forearm vascular resistance, and oxygen consumption were similar in the two groups. During supine leg exercise on a bicycle ergometer mean blood pressure increased in group 2 but did not change in group 1. Increases in cardiac index, pulmonary artery wedge pressure, and oxygen consumption during leg exercise were not significantly different in the two groups but forearm vascular resistance increased less in group 1 than in group 2. There was a positive correlation between the magnitude of the change in mean blood pressure and change in forearm vascular resistance during leg exercise. The impaired response of blood pressure to leg exercise in group 1 was not the result of a failure of the cardiac index to increase.

The results suggest the possibility that attenuation of reflex vasoconstriction in non-exercising muscles may contribute to the impaired response of blood pressure to exercise in patients with coronary artery disease.

In some patients with severe coronary artery disease the response of blood pressure to exercise is impaired..$^{1-3}$ The mechanisms for this are not known, although many believe that acute, ischaemia induced pump failure is responsible. ${ }^{14}$ But we know of no study that shows a decrease in cardiac output or the development of acute pump failure during exercise in patients with severe coronary artery disease.

A report that hypotension did not develop with pacing induced angina in patients who had exertional hypotension accompanying angina ${ }^{1}$ raises the possibility that the response of blood pressure to exercise is impaired by altered control of vascular resistance during exercise rather than myocardial ischaemia itself. It has been suggested that exertional hypoten-

Requests for reprints to Dr Akira Takeshita, Research Institute of Angiocardiology and Cardiovascular Clinic, Faculty of Medicine, Kyushu University, 3-1-1 Maidashi, Higashi-ku, Fukuoka 812, Japan.

Accepted for publication 12 August 1988 sion in patients with severe aortic stenosis may in part be the result of failure to produce reflex vasoconstriction in non-exercising muscles during exercise. ${ }^{5}$

We examined haemodynamic and forearm vascular responses to supine leg exercise with a cycle ergometer in patients with coronary artery disease who had a normal hypertensive response and in those in whom this response was impaired.

\section{Patients and methods}

We studied 18 patients with coronary artery disease (17 men and a woman, aged 39-72). Fourteen had a history of angina pectoris and 15 had had a myocardial infarction. In every patient coronary cineangiography showed coronary artery stenosis that reduced the luminal diameter by $>75 \%$. No patient had a history of congestive heart failure or syncope during exercise. Valve disease was excluded by cross sectional and Doppler echocardiograms in every patient. 
TREADMILL EXERCISE TESTING

The patients were tested on a treadmill by the Bruce protocol. ${ }^{6}$ During treadmill exercise testing the electrocardiogram was monitored and blood pressure was measured by a sphygmomanometer every minute and at the end of exercise. Exercise testing was stopped by chest pain in eight patients, dyspnoea in eight patients, horizontal ST depression $\geqslant 0.2 \mathrm{mV}$ in one patient, and the decrease in systolic blood pressure $\geqslant 10 \mathrm{~mm} \mathrm{Hg}$ in another.

The patients were divided into two groups according to whether their mean blood pressure decreased (group $1, n=8$ ) or increased (group $2, n=10$ ) in response to treadmill exercise testing. Mean blood pressure in group 1 fell by 3-15 $\mathrm{mm} \mathrm{Hg}$ (mean (SE) 8 (2) $\mathrm{mm} \mathrm{Hg}$ ) and increased in group 2 by $7-32 \mathrm{~mm} \mathrm{Hg}$ (mean (SE) 18 (3) $\mathrm{mm} \mathrm{Hg}$ ). We calculated mean blood pressure by adding one third of the pulse pressure to the diastolic blood pressure. We used the blood pressure value measured immediately before the end of exercise testing for classification. In 12 patients exercise testing was done while they were off all medication. Six patients (three in each group) underwent exercise testing while they were on antianginal drugs, which included isosorbide dinitrate in combination with diltiazem, nifedipine, or nicorandil. During exercise no patient fainted or had arrhythmias such as ventricular tachycardia or atrioventricular block.

\section{CARDIAC CATHETERISATION}

All antianginal drugs were stopped 24 hours before cardiac catheterisation, and minor tranquillisers (diazepam $5 \mathrm{mg}$ and pentobarbital $50 \mathrm{mg}$ ) were given orally 30 minutes before catheterisation. Pressures in the cardiac chambers and the aorta were measured by transducers (Bentley Tantec model 800). Cardiac output was measured by the thermodilution method and a thermocomputer (9520A Cardiac Output Computer, American Edwards Laboratories). Selective coronary angiography was performed in multiple projections by the Sones technique. Significant coronary stenosis was defined as a $\geqslant 75 \%$ reduction in the internal diameter. Biplane left ventriculography was performed in the $30^{\circ}$ right anterior oblique and $60^{\circ}$ left anterior oblique projections. The left ventricular volume was measured by the Dodge biplane method. ${ }^{7}$ The ejection fraction was calculated as follows: left ventricular stroke volume $\times$ $100 /$ left ventricular end diastolic volume.

\section{ERGOMETER EXERCISE TESTING}

After diagnostic cardiac catheterisation the patients performed leg exercise with a bicycle ergometer in a supine position at a workload of $20 \mathrm{~W}$ for six minutes. This low workload was chosen so that all patients would be able to exercise for at least six minutes for a complete set of measurements. At least 20 minutes were allowed for patients to recover from? diagnostic catheterisation. Aortic and pulmonary? artery wedge pressures were recorded and cardiaco output was measured by the thermodilution method? before and during the last three minutes of exercisea testing. The oxygen saturation of blood taken fromes the aorta and pulmonary artery was measured before and during the last minute of exercise testing:Oxygen consumption was calculated by multiplying $\vec{\omega}$ the arteriovenous oxygen difference by the cardiaco output. All patients completed six minutes of exercise testing without developing angina or severe? dyspnoea.

MEASUREMENTS OF FOREARM BLOOD FLOW

Blood flow in the forearm was measured throughout $\rightarrow$ ergometer exercise testing by a mercury in silastic ${ }^{\top}$ strain gauge plethysmograph and the venous occlusion technique. ${ }^{8}$ A strain gauge plethysmograph was placed around the left forearm approximately $₹$ $5 \mathrm{~cm}$ below the antecubital crease. The pressure in $\overrightarrow{0}$ the cuff was $40 \mathrm{~mm} \mathrm{Hg} .{ }^{9}$ Circulation to the hand was 0 stopped by inflating a cuff around the wrist to suprasystolic pressures when blood flow in the forearm was measured. We took the average of four to eight flow measurements made at 15 second intervals. Forearm vascular resistance was calculated by divid- $\bar{\Phi}$ ing mean aortic pressure $(\mathrm{mm} \mathrm{Hg})$ by forearm blood $\stackrel{\circ}{\rightarrow}$ flow $(\mathrm{ml} / \mathrm{min} / 100 \mathrm{ml}$ of forearm volume). These values are expressed as resistance units throughout this report. Forearm vascular resistances before exercise and during the last two minutes of exercise testing were compared.

\section{Table 1 Baseline characteristics (mean (SEM)) of} patients

\begin{tabular}{|c|c|c|c|}
\hline & Group 1 & Group 2 & $\begin{array}{l}\text { p value } \\
(\text { group } 1 \text { vs } \\
\text { group 2) }\end{array}$ \\
\hline $\begin{array}{l}\text { Number } \\
\text { Age (yr) } \\
\text { OMI: }\end{array}$ & $\begin{array}{l}8 \\
58(3)\end{array}$ & $\begin{array}{l}10 \\
53(3)\end{array}$ & $\overline{N S}$ \\
\hline $\begin{array}{l}\text { Total } \\
\text { Anteroseptal } \\
\text { Inferior }\end{array}$ & $\begin{array}{l}6 \\
3 \\
3\end{array}$ & $\begin{array}{l}9 \\
4 \\
5\end{array}$ & - \\
\hline $\begin{array}{l}\text { History of angina } \\
\text { CAD } 1 \mathrm{VD} / 2 \mathrm{VD} / 3 \mathrm{VD} \\
\text { RCA/LAD } / \mathrm{LCX} \\
\text { LVEF }(\%) \\
\text { LVEDP }(\mathrm{mm} \mathrm{Hg})\end{array}$ & $\begin{array}{l}7 \\
5 / 2 / 1 \\
5 / 6 / 1 \\
59(6) \\
13(3)\end{array}$ & $\begin{array}{l}7 \\
6 / 4 / 0 \\
5 / 6 / 3 \\
56(4) \\
16(3)\end{array}$ & $\begin{array}{l}- \\
\text { NS } \\
\text { NS }\end{array}$ \\
\hline
\end{tabular}

$\star_{t}$ T Test.

OMI, old myocardial infarction; CAD, coronary artery disease VD, vessel disease; RCA, LAD, LCX-right, left anteriof descending, and left circumflex artery respectively; LVEF, lef ventricular ejection fraction; LVEDP, left ventricular end diastoliø pressure. 
Table 2 Heart rate and blood pressure responses to standing and treadmill exercise and the duration of exercise

\begin{tabular}{|c|c|c|c|c|c|}
\hline & & & $\begin{array}{l}\text { Group 1 } \\
(n=8)\end{array}$ & $\begin{array}{l}\text { Group 2 } \\
(n=10)\end{array}$ & $\begin{array}{l}\text { p value } \\
\text { (Group } 1 \text { vs Group 2) }\end{array}$ \\
\hline HR (beats/min) & $\begin{array}{l}\text { Systolic: } \\
\text { Diastolic: } \\
\text { Mean: }\end{array}$ & $\begin{array}{l}\text { Rest } \\
\text { Standing } \\
\text { End of exercise } \\
\text { Rest } \\
\text { Standing } \\
\text { End of exercise } \\
\text { Rest } \\
\text { Standing } \\
\text { End of exercise } \\
\text { Rest } \\
\text { Standing } \\
\text { End of exercise }\end{array}$ & $\begin{array}{l}133(8) \\
132(6) \\
132(7) \\
80(5) \\
85(4) \star \\
73(4) \# \# \# \\
98(6) \\
100(5) \\
92(5) \# \# \\
70(8) \\
82(6) \star \star \\
121(9) \# \# \# \\
5.5(0.5)\end{array}$ & $\begin{array}{l}120(5) \\
121(6) \\
163(8) \# \# \# \\
76(5) \\
82(5) \star \\
88(5) \\
91(5) \\
95(5) \\
113(6) \# \# \# \\
72(3) \\
87(4) \star \star \star \\
139(5) \# \# \# \\
6.8(0.8)\end{array}$ & $\begin{array}{l}\text { NS } \\
\text { NS } \\
<0.02 \\
\text { NS } \\
\text { NS } \\
<0.05 \\
\text { NS } \\
\text { NS } \\
<0.02 \\
\text { NS } \\
\text { NS } \\
\text { NS } \\
\text { NS }\end{array}$ \\
\hline
\end{tabular}

$\star, \star \star, \star \star \star \mathrm{p}<0.05, \mathrm{p}<0.01, \mathrm{p}<0.001$, respectively for rest $v$ standing.

$\$ \#, \$ \# \$ p<0.01, p<0.001$, respectively for standing $v$ end of exercise.

$B P$, blood pressure; HR, heart rate.

\section{COLD PRESSOR TEST}

We examined whether the impaired response of blood pressure to exercise in patients in group 1 was caused by non-specific abnormalities in neurogenic vasoconstriction by comparing the blood pressure response to the cold pressor test in six patients from each group. The patients lay quietly for 15 minutes before testing. When the basal blood pressure was

Table 3 Haemodynamic responses to ergometer exercise

\begin{tabular}{|c|c|c|c|c|}
\hline Variable & & $\begin{array}{l}\text { Group 1 } \\
(n=8)\end{array}$ & $\begin{array}{l}\text { Group } 2 \\
(n=10)\end{array}$ & $\begin{array}{l}\text { p value } \\
\text { (group 1 } \\
\text { vs } \\
\text { group 2) }\end{array}$ \\
\hline HR (beats/min): & $\begin{array}{l}\mathbf{R} \\
\text { Ex }\end{array}$ & $\begin{array}{l}73(4) \\
88(5)^{\star \star} \\
15(3)\end{array}$ & $\begin{array}{l}83(4) \\
100(3)^{\star \star \star} \\
17(2)\end{array}$ & $\begin{array}{l}\text { NS } \\
<0.05 \\
\text { NS }\end{array}$ \\
\hline PAWP (mm Hg) & $\begin{array}{l}\mathbf{R} \\
\mathbf{E X}\end{array}$ & $\begin{array}{l}13(2) \\
18(3)^{\star} \\
6(2)\end{array}$ & $\begin{array}{l}11(2) \\
18(3)^{\star \star} \\
6(1)\end{array}$ & $\begin{array}{l}\text { NS } \\
\text { NS } \\
\text { NS }\end{array}$ \\
\hline $\mathbf{S A P}(\mathbf{m m ~ H g})$ & $\begin{array}{l}\mathbf{R} \\
\mathbf{E X}\end{array}$ & $\begin{array}{r}141(5) \\
142(7) \\
1(5)\end{array}$ & $\begin{array}{l}129(7) \\
153(8)^{\star \star \star} \\
23(4)\end{array}$ & $\begin{array}{l}\text { NS } \\
\text { NS } \\
<0.01\end{array}$ \\
\hline $\mathrm{DAP}(\mathrm{mm} \mathrm{Hg})$ & $\begin{array}{l}\mathbf{R} \\
\mathbf{E X}\end{array}$ & $\begin{array}{r}79(4) \\
79(3) \\
0(2)\end{array}$ & $\begin{array}{l}77(5) \\
85(5)^{\star} \\
8(3)\end{array}$ & $\begin{array}{l}\text { NS } \\
\text { NS } \\
\Delta 0.05\end{array}$ \\
\hline MAP (mm Hg): & EX & $\begin{array}{l}106(4) \\
105(4) \\
-1(2)\end{array}$ & $\begin{array}{l}100(5) \\
115(6)^{\star \star \star} \\
14(3)\end{array}$ & $\begin{array}{l}\text { NS } \\
\text { NS }\end{array}$ \\
\hline $\mathrm{CI}\left(\mathrm{l} / \mathrm{min} / \mathrm{m}^{2}\right):$ & $\begin{array}{l}\mathbf{R} \\
\mathbf{E x} \\
\triangle\end{array}$ & $\begin{array}{l}3.9(0.2) \\
4.6(0.3)^{\star \star} \\
0.7(0.2)\end{array}$ & $\begin{array}{l}4.1(0 \cdot 3) \\
5 \cdot 2(0 \cdot 3)^{\star \star} \\
1 \cdot 1(0 \cdot 3)\end{array}$ & $\begin{array}{l}\text { NS } \\
\text { NS } \\
\text { NS }\end{array}$ \\
\hline $\begin{array}{l}\text { SVRI } \\
\left(\operatorname{mm} \mathrm{Hg} / 1 / \mathrm{min} / \mathrm{m}^{2}\right)\end{array}$ & EX & $\begin{array}{l}28.0(1 \cdot 6) \\
23.6(1 \cdot 7)^{\star \star}\end{array}$ & $\begin{array}{l}25 \cdot 4(2 \cdot 3) \\
22 \cdot 8(2 \cdot 1)^{\star}\end{array}$ & $\begin{array}{l}\text { NS } \\
\text { NS }\end{array}$ \\
\hline$\dot{\mathrm{Vo}}_{2}(\mathrm{ml} / \mathrm{min}):$ & $\begin{array}{l}\Delta \\
\mathbf{R} \\
\mathbf{E X} \\
\underset{\Delta}{\operatorname{EX}} / \mathbf{R}(\%)\end{array}$ & $\begin{array}{l}-4 \cdot 5(1 \cdot 2) \\
239(11) \\
500(39)^{\star \star \star} \\
209(15) \\
261(35)\end{array}$ & $\begin{array}{l}-2 \cdot 6(1 \cdot 0) \\
232(20) \\
580(38)^{\star \star \star} \\
580(38)^{\star \star \star} \\
348(32)\end{array}$ & $\begin{array}{l}\text { NS } \\
\text { NS } \\
\text { NS } \\
\text { NS } \\
\text { NS }\end{array}$ \\
\hline
\end{tabular}

$\star{ }^{\star \star}, \star \star \star \mathrm{p}<0.05, \mathrm{p}<0.01, \mathrm{p}<0.001$ respectively for rest $v$ exercise.

HR, heart rate; PAWP, pulmonary artery wedge pressure; SAP, systolic aortic pressure; DAP, diastolic aortic pressure; MAP, mean aortic pressure; CI, cardiac index; SVRI, systemic vascular resistance index: $\mathrm{VO}_{2}$, oxygen consumption; $\mathrm{R}=$ at rest; $\mathrm{EX}$, during exercise; $\Delta$, difference between $R$ and $E X ; N S$, not significant. stable they put a hand in ice water for one minute. Blood pressure was measured by a sphygmomanometer before and at the end of the cold stimulus.

\section{STATISTICAL ANALYSIS}

All data were expressed as mean (SEM). Statistical analysis was performed by the analysis of variance, $F$ test, $t$ test, and paired $t$ test where indicated. A p value of $<0.05$ was regarded as significant.

\section{Results}

BASELINE VALUES (TABLE 1)

Age and the frequency of a history of myocardial infarction were similar in the two groups. The extent and distribution of coronary artery disease were also similar, as were resting left ventricular end diastolic pressure and left ventricular ejection fraction.

RESPONSES TO TREADMILL EXERCISE (TABLE 2)

Systolic, diastolic, and mean blood pressure and heart rate in recumbent and standing patients before the start of exercise testing were similar in the two groups. There was no orthostatic hypotension in either group. During treadmill exercise, systolic and mean blood pressure increased ( $p<0.01$ for each) in group 2 whereas in group 1 systolic blood pressure did not change and diastolic and mean blood pressure decreased ( $p<0.001$, and $p<0.01$ respectively). The duration of exercise testing did not differ in the two groups.

\section{RESPONSES TO ERGOMETER EXERCISE (TABLE 3)} Measurements of heart rate; pulmonary artery wedge pressure; systolic, diastolic, and mean blood pressure; cardiac index; systemic vascular resistance index; and oxygen consumption were similar at rest in the two groups. During ergometer exercise, heart 
Table 4 Response of forearm blood flow and forearm vascular resistance to ergometer exercise

\begin{tabular}{|c|c|c|c|c|}
\hline & & $\begin{array}{l}\text { Group } 1 \\
(n=8)\end{array}$ & $\begin{array}{l}\text { Group 2 } \\
(n=10)\end{array}$ & $\begin{array}{l}\text { p value } \\
\text { (group 1 } \\
\text { vs group 2) }\end{array}$ \\
\hline $\begin{array}{l}\text { FoBF } \\
(\mathrm{ml} / \mathrm{min} / 100 \mathrm{~g}) \text { : } \\
\text { FoVR } \\
\text { units })\end{array}$ & $\begin{array}{l}\mathrm{R} \\
\mathrm{EX} \\
\Delta \\
\mathrm{R} \\
\mathrm{EX} \\
\Delta\end{array}$ & $\begin{array}{r}4.2(0.5) \\
3.7(0.5) \\
-0.5(0.3) \\
27.5(2.7) \\
30.2(2.4) \\
2.7(1.4)\end{array}$ & $\begin{array}{l}5.7(0.7) \\
3.9(0.5)^{\star \star \star} \\
-1.8(0.4) \\
20.6(3.3) \\
33.8(4.9)^{\star \star} \\
13.2(2.8)\end{array}$ & $\begin{array}{l}\text { NS } \\
\text { NS } \\
<0.01 \\
\text { NS } \\
\text { NS } \\
<0.01\end{array}$ \\
\hline
\end{tabular}

$\star \star, \star \star \star p<0.01, p<0.001$ respectively, for rest $v$ exercise. FoBF, forearm blood flow; FoVR, forearm vascular resistance; $R$, at rest; EX, during exercise; $\Delta$, difference between rest and exercise.

rate, pulmonary artery wedge pressure, cardiac index, and oxygen consumption increased and systemic vascular resistance index decreased in both groups. Systolic, diastolic, and mean blood pressure increased during ergometer exercise in group 2 whereas they did not change in group 1 . The sizes of the changes in pulmonary artery wedge pressure, cardiac index, systemic vascular resistance index, and oxygen consumption induced by exercise were not significantly different in the two groups. Heart rate during exercise was higher in group 2 than in group 1 but the size of the increase in heart rate induced by exercise was not different in the two groups.

\section{CHANGES IN FOREARM VASCULAR RESISTANCE DURING ERGOMETER EXERCISE (TABLE 4)}

Forearm blood flow decreased and forearm vascular resistance increased during leg exercise on a bicycle ergometer in group 2 patients but they did not

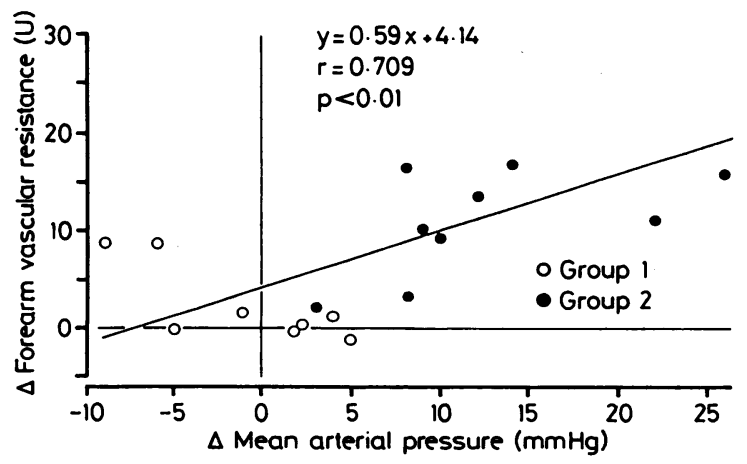

Figure Relation between increase in mean blood pressure $(x)$ and increase in forearm vascular resistance during ergometer exercise (y). There was a positive correlation between them.
Table 5 Response of systolic, diastolic, and mean blood pressure to the cold pressor test

\begin{tabular}{|c|c|c|c|c|}
\hline & & Group 1 & Group 2 & $\begin{array}{l}\text { p value } \\
\text { (group } 1 \text { vs } \\
\text { group 2) }\end{array}$ \\
\hline $\begin{array}{l}\text { SBP } \\
(\mathbf{m m} \mathbf{H g}):\end{array}$ & $\begin{array}{l}\text { Before } \\
\text { CPT } \\
\triangle\end{array}$ & $\begin{array}{l}133(7) \\
150(9)^{\star \star} \\
17(3)\end{array}$ & $\begin{array}{l}117(8) \\
134(8) \star \star \star \\
17(2)\end{array}$ & $\begin{array}{l}\text { NS } \\
\text { NS } \\
\text { NS }\end{array}$ \\
\hline $\begin{array}{l}\text { DBP } \\
(\mathrm{mm} \mathrm{Hg})\end{array}$ & $\begin{array}{l}\text { Before } \\
\text { CPT } \\
\triangle\end{array}$ & $\begin{array}{l}77(4) \\
90(4)^{\star \star} \\
13(3)\end{array}$ & $\begin{array}{l}72(7) \\
87(6) \\
15(3)\end{array}$ & $\begin{array}{l}\text { NS } \\
\text { NS } \\
\text { NS }\end{array}$ \\
\hline $\begin{array}{l}\text { MBP } \\
(\mathrm{mm} \mathrm{Hg}):\end{array}$ & $\begin{array}{l}\text { Before } \\
\text { CPT } \\
\triangle\end{array}$ & $\begin{array}{l}96(4) \\
110(5)^{\star \star} \\
14(2)\end{array}$ & $\begin{array}{r}87(7) \\
103(7) \\
16(2)\end{array}$ & $\begin{array}{l}\text { NS } \\
\text { NS } \\
\text { NS }\end{array}$ \\
\hline
\end{tabular}

$\star \star, \star \star \star p<0.01, p<0.001$ respectively for values before and $\sigma$ after the cold pressor test.

SBP, DBP, MBP, systolic, diastolic and mean blood pressure, respectively; CPT, cold pressor test; $\triangle$, difference between the values before and during the cold pressor test.

significantly change in group 1 patients. The sizes of changes in forearm blood flow and forearm vascular resistance were significantly different in the twogroups. There was a positive correlation between the $\mathscr{\infty}$ increases in mean blood pressure and increases in. forearm vascular resistance during ergometer exercise $(y=0.59 x+4.14, r=0.71, p<0.01)$ (figure).

\section{BLOOD PRESSURE RESPONSES TO THE COLD PRESSOR TEST (TABLE 5)}

Systolic, diastolic, and mean blood pressure increased with the cold pressor test in both groups. The increases in blood pressure with the cold pressor test were not significantly different in the two groups.

\section{Discussion}

From the results of this study we conclude that the impaired blood pressure response to ergometer exercise in group 1 was not the result of a failure to $\frac{1}{3}$ increase cardiac output and that the impaired blood pressure response to ergometer exercise was associated with less vasoconstriction in the non- No exercising forearm. There was a positive correlation between the magnitude of reflex vasoconstriction in non-exercising forearm and the rise in blood pressure $\omega$ during ergometer exercise. These results suggest that impaired reflex vasoconstriction in non-exercising ${ }^{\circ}$ muscles may have contributed to abnormal blood $₫$ pressure response to ergometer exercise in these ? patients with coronary artery disease.

Other cardiac disorders including obstructive $\frac{\vec{D}}{\mathrm{D}}$ valvar disease, particularly aortic and mitral stenosis, $\frac{?}{\mathbb{Q}}$ and severe left ventricular dysfunction may cause $ᄋ$ exertional hypotension. Exertional hypotension may 
occur in association with exercise induced arrhythmias. However, none of these abnormalities was present in our patients. Drugs such as $\beta$ blockers can also cause exertional hypotension. ${ }^{10}$ Our patients were not on $\beta$ blockers. Three patients in group 1 were on isosorbide dinitrate in combination with diltiazem or nifedipine. These drugs do not reduce the increase in blood pressure that occurs with exercise. ${ }^{112}$ Three patients in group 2 were on similar drugs but did not have impaired blood pressure response to exercise. Also it has been shown that exertional hypotension can occur in normal subjects at the beginning of exercise $e^{413}$ or during maximal exhaustive exercise. ${ }^{14}{ }^{15}$ In our patients blood pressure was measured after an average of 5.5 minutes of submaximal exercise. Thus we consider that the impaired blood pressure response to exercise in our patients was probably related to coronary artery disease. Furthermore, blood pressure responses to the cold pressor test were similar in the two groups, which suggests that impaired blood pressure response to exercise in group 1 was unlikely to have been the result of non-specific autonomic dysfunction.

In this study the patients had two types of exercise testing. The patients were divided into two groups on the basis of the blood pressure response to treadmill exercise as in previous studies ${ }^{1013}$ and haemodynamic and forearm vascular responses to exercise were examined during supine leg exercise with a bicycle ergometer. This protocol was chosen because reliable measurements of forearm blood flow in a resting forearm were possible only with patients in a supine position. The workload on the ergometer was smaller than that with a treadmill so that all patients could exercise for six minutes and all the measurements could be completed. There were some differences in blood pressure responses between treadmill and ergometer exercise in groups 1 and 2 (tables 1 and 2), which were likely to have resulted from differences in workloads and body position. Patients with impaired blood pressure responses to treadmill exercise also had impaired blood pressure response to less demanding exercise on a bicycle ergometer.

We found that the increase in cardiac output during ergometer exercise was not significantly different in the two groups despite different blood pressure responses. Failure to increase cardiac output during exercise did not account for the impaired blood pressure response during exercise in group 1 . The increases in pulmonary artery wedge pressure during ergometer exercise also were similar in the two groups, suggesting that the development of acute left ventricular pump failure in group 1 was unlikely.

Thompson and Kelemen reported that patients who had hypotension accompanying angina during treadmill exercise did not develop hypotension with pacing induced angina in the supine position. ${ }^{1}$ These results suggest that impaired blood pressure response to exercise in their patients was unlikely to have been the result of the development of myocardial ischaemia itself. It was more likely to have been related to altered control of vascular resistance during exercise. The results of our study are consistent with this view. We found that there was less reflex vasoconstriction in the forearm during leg exercise with an ergometer in patients with impaired blood pressure response to an ergometer and to treadmill exercise than in patients who had a normal hypertensive response. Furthermore, there was a positive correlation between the increase in blood pressure and the degree of reflex forearm vasoconstriction during ergometer exercise. We believe that impaired reflex vasoconstriction in nonexercising muscles might have contributed to impaired blood pressure response to exercise.

We cannot be certain what mechanisms impaired reflex vasoconstriction in the forearm during leg exercise in patients who had impaired blood pressure response to exercise. Reflex sympathetic activation during exercise may be mediated by a somatic receptor reflex originating in exercising muscles. ${ }^{16}{ }^{17}$ It also has been shown that reflex sympathetic activation mediated by a somatic receptor reflex may be attenuated by simulation of the cardiac receptors. ${ }^{119}$ Thus an attenuation of reflex forearm vasoconstriction in patients who had impaired blood pressure response to exercise might have resulted from impaired somatic receptor reflex during exercise or from greater activation of the cardiac receptors. To examine the possibility that activation of the cardiac receptors during exercise might have been greater in patients with an impaired blood pressure response than in those with a normal hypertensive response, we examined the increase in pulmonary artery wedge pressure during exercise and the distribution of coronary artery disease. Cardiac receptors are stimulated by an increase in left ventricular diastolic pressure ${ }^{20}$ and there are more of them in the inferior wall of the left ventricle. ${ }^{2122}$ But the increase in pulmonary artery wedge pressure and the distribution of coronary artery disease were similar in the two groups. Further studies are needed to clarify the mechanisms that impair reflex forearm vasoconstriction during leg exercise in patients with impaired blood pressure response to exercise.

In summary, patients who had impaired blood pressure response to treadmill exercise also showed an impaired blood pressure response to less strenuous exercise on an ergometer. The impaired blood pressure response to ergometer exercise was not accounted for by a failure to increase cardiac 
output during exercise but was accompanied by attenuated reflex vasoconstriction in non-exercising muscles. Although the mechanisms are not clear, the results of this study suggest that altered control of vascular resistance during exercise may contribute to impaired blood pressure response to exercise at least in some patients with coronary artery disease.

We thank Dr Hisatsune Ootsubo and Dr Takeshi Inoue for their help with the catheter studies.

This study was supported by a grant from the Ministry of Education, Science, and Culture.

\section{References}

1 Thomson PD, Kelemen MH. Hypotension accompanying the onset of exertional angina. A sign of severe compromise of left ventricular blood supply. Circulation 1975;52:28-32.

2 Sanmarco ME, Pontius S, Selvester RH. Abnormal pressure response and marked ischemic ST-segment depression as predictors of severe coronary artery disease. Circulation 1980;61:572-8.

3 Anderson RP, Balfour RI, Horton WG. Surgical management of left main coronary artery stenosis and ischemic left ventricular dysfunction. $J$ Thorac Cardiovasc Surg 1979:77:369-76.

4 Morris SN, Phillips JF, Jordan JW, McHenry PL. Incidence and significance of decreases in systolic blood pressure during graded treadmill exercise testing. Am J Cardiol 1978;41:221-6.

5 Mark AL, Kioschos JM, Abboud FW, Heistad DD, Schmid PG. Abnormal vascular responses to exercise in patients with aortic stenosis. J Clin Invest 1973;52:1138-46.

6 Bruce RA. Exercise testing of patients with coronary heart disease. Principles and normal standards for evaluation. Ann Clin Res 1971;3:323-32.

7 Dodge HT, Sandler H, Ballew DW, Lord JD. The use of biplane angiocardiography for measurement of left ventricular volume in man. Am Heart $J$ 1960;60: 762-76.

8 Whitney BR. The measurement of volume changes in human limbs. J Physiol (Lond) 1953;121:1-27.
9 Folkow B, Grimby G, Thulesius O. Adaptive structural $C$ changes in the vascular wall in hypertension and their relation to the control of peripheral resistance. Actass Physiol Scand 1958;44:255-72.

10 Hammermeister KE, DeRouen TA, Dodge TA, Zia M.O Prognostic and predictive value of exertionale hypotension in suspected coronary heart disease. $A m \overrightarrow{\mathrm{D}}$ $J$ Cardiol 1983;51:1261-6.

11 Leon MB, Rosing DR, Bonow RO, Lipson LC, Epsteines SE. Clinical efficacy of verapamil alone and combinedwith propranolol in treating patients with chronicstable angina pectoris. Am J Cardiol 1981;48:131-9. $\vec{\omega}$

12 Hossack KF, Bruce RA. Improved exercise performance in persons with stable angina pectoris receiving diltiazem. Am J Cardiol 1977;39:849-51.

13 Levites R, Baker T, Anderson GJ. The significance of hypotension developing during treadmill exercise testing. Am Heart J 1978;95:747-53.

14 Sallin B, Sternberg J. Circulatory response to prolonged severe exercise. J Appl Physiol 1964;19? 833-8.

$15 \mathrm{Li}$ YB, Ting N, Chiang BN, Alexander ER, Bruce R, $\frac{\mathbb{D}}{\mathrm{O}}$ Grayston JT. Electrocardiographic response to maximal exercise. Am J Cardiol 1967;20:541-8.

16 Bevegard B, Shepherd J. Reaction in man of resistance and capacitance vessels in forearm and hand to lege exercise. J Appl Physiol 1966;21:123-32.

$17 \mathrm{McCloskey} \mathrm{D,} \mathrm{Mitchell} \mathrm{J.} \mathrm{Reflex} \mathrm{cardiovascular} \mathrm{and}$ respiratory responses originating in exercisingo muscle. J Physiol (Lond) 1972;224:173-86.

18 Walker JL, Abboud FM, Mark AL, Thames MD. Interaction of cardiopulmonary and somatic reflexesô in humans. J Clin Invest 1980;65:1491-7.

19 Thames MD, Abboud FM. Interaction of somatic and cardiopulmonary receptors in control of renal circula- 음 tion. Am J Physiol 1980;237:H784-8.

20 Thoren P. Characteristics of left ventricular receptors with nonmedullated vagal afferents in cats. Circ Res. 1977;40:415-21.

21 Felder RB, Thames MD. Interaction between cardiac receptors and sinoaortic baroreceptors in the controf of efferent cardiac sympathetic nerve activity during myocardial ischemia in dogs. Circ Res 1979;45 728-36.

22 Thames MD, Abboud FM. Reflex inhibition of renal sympathetic nerve activity during myocardia: ischemia mediated by left ventricular receptors with $>$ vagal afferents in dogs. J Clin Invest 1979;63:395-402. 